\title{
PEMBELAJARAN FISIKA BERBANTUKAN MEDIA SOSIAL FACEBOOK DAN DAMPAKNYA TERHADAP HASIL BELAJAR FISIKA
}

\author{
Susilawati $^{1}$ \\ Intan Wulan Sari ${ }^{2}$ \\ Program Studi Pendidikan Fisika, FKIP, Universitas Syiah Kuala ${ }^{1}$ \\ Prodi Megister Pendidikan IPA, Program Pasca Sarjana Universitas Syiah Kuala ${ }^{2}$ \\ Email: susila@unsyiah.ac.id
}

\begin{abstract}
The current era of technology requires the ability to use learning that combines the use of information technology and communication to improve learning outcomes. So that the use of technology products in learning needs serious attention. The purpose of this study was to determine the effect of Facebook social media assisted learning on the results of learning physics on the topic of the solar system. The method used in this research is quasi-experiment with the design of one group pretest posttest. This research was conducted at Rukoh Banda Aceh MTsN in class VII students with a total sample of 59 students. Through the random sampling method selected the VIIA class as the experimental class which was given a learning treatment assisted by social media Facebook. While the VIID class was chosen as the control class taught by the question and answer discussion method. Data processing techniques through t-test with SPSS version 20. After the requirements analysis, the data obtained that the two classes meet the requirements for normality and homogeneity. The results of the t test obtained $t$ count 25.58 where $t$ table 16.9 then $t$ table <t count is $16.9<25.58$ so Ho is rejected and Ha is accepted. These results indicate that there is an effect of learning assisted by social media Facebook on student learning outcomes. Based on the results of Paired Samples Test and Paired samples correlations, the value of sig (2-tailed) 0,000<0,05 indicates that there is a significant influence of learning assisted by Facebook social networking on the results of learning physics on the topic of the solar system.
\end{abstract}

Keywords: Facebook social media, technology, learning outcomes.

\section{PENDAHULUAN}

Saat ini perkembangan teknologi

dan informasi berkembang pesat, sehingga menjadi hal yang wajar jika para ahli menyebut ini sebagai suatu revolusi. Kemajuan teknologi ini dapat diprediksi akan menyebabkan berbagai perubahan di bidang 
Susilawati., I, W, Sari. - Pembelajaran Fisika Berbantukan ...

informasi dan bidang kehidupan lainnya sebagai implikasi dari perkembangan teknologi tersebut. Kondisi ini juga mendorong berkembangnya konsep pembelajaran yang memanfaatkan teknologi informasi untuk kemudahan proses pembelajaran.

Saat ini produk teknologi telah berhasil menarik perhatian masyarakat dari berbagai kalangan dengan variasi desain produknya yang mampu membantu dan meringankan pekerjaan manusia menjadi lebih mudah, cepat dan efisien. Salah satunya pemanfaatan gawai atau sering disebut smartphone sebagai alat komunikasi yang dianggap efektif. Sehingga smartphone juga dapat digunakan sebagai media pembelajaran yang mampu mempermudah pencapaian tujuan pembelajaran dan meningkatkan motivasi siswa dalam belajar (Abdelraheem, \& Ahmed, 2018). Hasil survey terhadap siswa sekolah menengah yang ada di kota Banda Aceh menunjukkan hasil bahwa $77 \%$ siswa sudah menggunakan smartphone dan $76 \%$ siswa menyebutkan bahwa mereka tertarik menggunakan smartphone sebagai alat komunikasi (Rosalina \& Wahyuni, 2017)

Salah satu fasilitas yang tersedia pada smartphone yaitu situs jejaring sosial yang marak digunakan sebagian besar siswa untuk berbagai keperluan. Melalui penggunaan smartphone, aplikasi jejaring sosial telah popular diberbagai komunitas masyarakat.Situs ini dianggap sangat berguna karena menyebabkan seseorang dapat terus berhubungan dengan masyarakat luas tanpa dibatasi ruang dan waktu (Rusman \& Kurniawan, 2011; Chatterjee, 2014; Jesse, 2015). Terlebih lagi, aplikasi jejaring sosial saat ini menjadi salah satu sarana komunikasi yang paling banyak diminati siswa dari berbagai jenjang pendidikan. Dari beberapa situs jaringan sosial, aplikasi yang paling digemari adalah Facebook, Twitter, Whatsup, Youtube dan MySpace (Chatterjee, 2014). Jaringan sosial ini menjadi pola baru dalam berkomunikasi di era revolusi yang sering disebut media sosial. Berbagai penelitian menunjukakan bahwa aplikasi jejaring sosial memberikan kemudahan dalam kegiatan 
Susilawati., I, W, Sari. - Pembelajaran Fisika Berbantukan ...

pembelajaran yang dilakukan siswa secara kolaboratif (Alvarez, Alarcon, \& Nussbaum, 2011; Chiang, Yang \& Hwang, 2014).

Jaringan media sosial merupakan sarana media melalui dunia maya yang memberi kemudahan bagi manusia dalam melakukan komunikasi dan berinteraksi (Murray \& Waller, 2007).

Secara umum siswa sekolah menengah sangat aktif menggunakan media sosial dalam bersosialisasi dan berkomunikasi sesama siswa (Sari, Widyanto, \& Kamal, 2017). Saat ini facebook dikenal sebagai salah satu jejaring sosial online yang paling popular dan banyak diminati kalangan remaja (Cheung, Chiu \& Lee, 2011). Model baru dalam berkomunikasi di era revolusi ini memberikan pengaruh penting terhadap motivasi siswa dalam belajar, bersosialisasi dan menciptakan suasana kelas yang positif (Mazer, Murphy, \& Simonds, 2007). Oleh karena itu, kegiatan pembelajaran perlu menciptakan ruang sosial online yang mampu membangun dan memelihara hubungan sosial dengan orang lain (Ellison, Steinfield, \& Lampe, 2007;
Lytras dan Garcia, 2008). Bentuk komunikasi dan aktivitas online ini menjadi sangat positif apabila dapat dimanfaatkan sebagai media dalam aktivitas pembelajaran.

Penggunaan berbagai media dalam pembelajaran dapat dilakukan dengan berbagai variasi dan disertai berbagi metode pembelajaran yang cocok. Supardi (2010) menyebutkan pembelajaran menggunakan berbagai media dapat memotivasi dan memberi pengaruh psikologis siswa untuk lebih semangat belajar. Melalui penggunaan media, guru tidak hanya mengajar melalui komunikasi verbal seperti ceramah yang menyebabkan siswa bosan mengikuti pelajaran.Oleh karena itu, diera teknologi informasi ini facebook menjadi salah satu media yang sesuai untuk untuk melakukan peran tersebut. Pendapat ini sejalan dengan penelitian Yulita., Rustiyarso, \& Genjik (2013) yang menyebutkan bahwa media sosial facebook dianggap sebagai media berbasis teknologi yang efektif digunakan dalam pembelajaran. Selain mampu menjadi sarana komunikasi, facebook juga menyajikan informasi yang dibutuhkan dan siswa terbiasa 
Susilawati., I, W, Sari. - Pembelajaran Fisika Berbantukan ...

mengakses situs ini setiap hari di manapun mereka berada.

Perkembangan teknologi tidak hanya memberikan dampak positif bagi manusia. Berbagai dampak negatif juga timbul dari kemajuan teknologi ini jika tidak disikapi dengan baik. Facebook adalah salah satu produk teknologi yang berkembang pesat dikalangan remaja. Penggunaan facebook menempati urutan pertama sebagai jejaring sosial yang paling banyak diminati diantara situslainnya. Umumnya pengguna facebook di Indonesia berasal dari kalangan anak-anak hingga dewasa, paling banyak berasal dari kalangan remaja.Sebagian besar remaja telah menggunakan media sosial ini (Lagiono, 2012).

Maraknya penggunaan facebook dikalangan usia sekolah mejadikan situs ini jarang digunakan untuk aktivitas pembelajaran, malah cenderung dimanfaatkan untuk aktivitas yang melalaikan. Sehingga kondisi ini menuntut guru mampu melakukan inovasi dengan memanfaatkan media untuk meningkatkan motivasi belajar siswa.
Sesuai dengan perkembangan teknologi informasi, pemanfaatan facebook sebagai forum diskusi dapat meningkatkan interaksi dan keterlibatan siswa di luar jam pelajaran. Hal ini sesuai dengan pendapat Fitriyadi, Herry (2013) yang menyatakan bahwa teknologi informasi dan komunikasi sangat bermanfaat dengan keanekaragaman jenis teknologi tersebut. Pemanfaatan teknologi untuk aktivitas pembelajaran dapat menjadi alternatif penyampaian materi ajar yang bersifat abstrak (Yusuf \& Widyaningsih, 2018). Kelebihan teknologi ini mampu dijangkau oleh siswa dimana dan kapan saja. Hal ini berdampak terhadap perubahan revolusioner dalam pendidikan tradisional dengan menghilangkan paradigma anggapan waktu untuk belajar adalah waktu ketika berada di kelas. Keberadaan teknologi dalam pembelajaran memungkinkan siswa saling berinterasksi sesama siswa atau dengan guru tanpa dibatasi ruang dan waktu.

Studi yang dilakukan Ariyani (2010) menyebutkan bahwa situs jejaring sosial facebook memiliki 
Susilawati., I, W, Sari. - Pembelajaran Fisika Berbantukan ...

banyak kelebihan yang dapat yang sedang mereka pelajari. Ketika dimanfaatkan untuk aktivitas siswa mendapatkan teks bacaan pembelajaran. Beberapa kelebihan terkait topik yang dipelajari, dengan tersebut yaitu: jejaring sosial mudah siswa dapat membagi facebook bersifat informatif, memiliki fitur grouping sebagai wadah informasi tersebut kepada sesama komunikasi sesama teman kelompok, komunikasi dengan orang lain dapat dengan mudah dilakukan pengecekan, pengguna dapat menampilkan foto, video atau berbagai tautan website internet yang sesuai dengan konten pembelajaran sehingga dapat memperluas sumber informasi dari materi pelajaran yang didapatkan. Hal senada juga diungkapkan Lagiono (2012) yang menyebutkan bahwa untuk meningkatkan aktivitas pembelajaran, berbagai aplikasi situs sosial facebook dapat menjadi salah satu media alternatif yang efektif. Umumnya siswa merasa konten informasi yang sediakan media facebook lebih menarik untuk dibaca dibandingkan dengan materi bacaan yang ada dalam buku paket. Selain penyajian gambar yang berwarna, melalui facebook siswa juga dapat langsung menjangkau website yang menyediakan informasi lebih lengkap dan komprehensif tentang materi teman dan mendiskusikannya melalui fitur group massage tanpa harus menunggu jam pelajaran sekolah dan hadir didalam kelas. Kelebihan ini memudahkan siswa untuk belajar mandiri, berinteraksi dengan guru dan bertukar informasi sesama teman sekelas maupun kelas yang berbeda (Richardson \& Stanyer, 2011; Singer,2014).

Referensi yang digunakan dalam pembelajaran tidak hanya bersumber dari buku teks, namun informasi terkait materi yang sedang dipelajara juga dapat diperoleh melalui sharing dan komunikasi. Pada era tradisional segala aspek pembelajaran terbatas pada fisik ruang kelas, sehingga siswa sulit mengaitkan pengalaman yang mereka peroleh sehari-hari dengan konten materi. Kondisi ini menyebabkan siswa seolah-olah mempelajari sesuatu yang abstrak dan sulit ditemukan. Salah satu contohnya adalah materi fisika yang selama ini dianggap sulit dipelajari dan dikaitkan 
Susilawati., I, W, Sari. - Pembelajaran Fisika Berbantukan ...

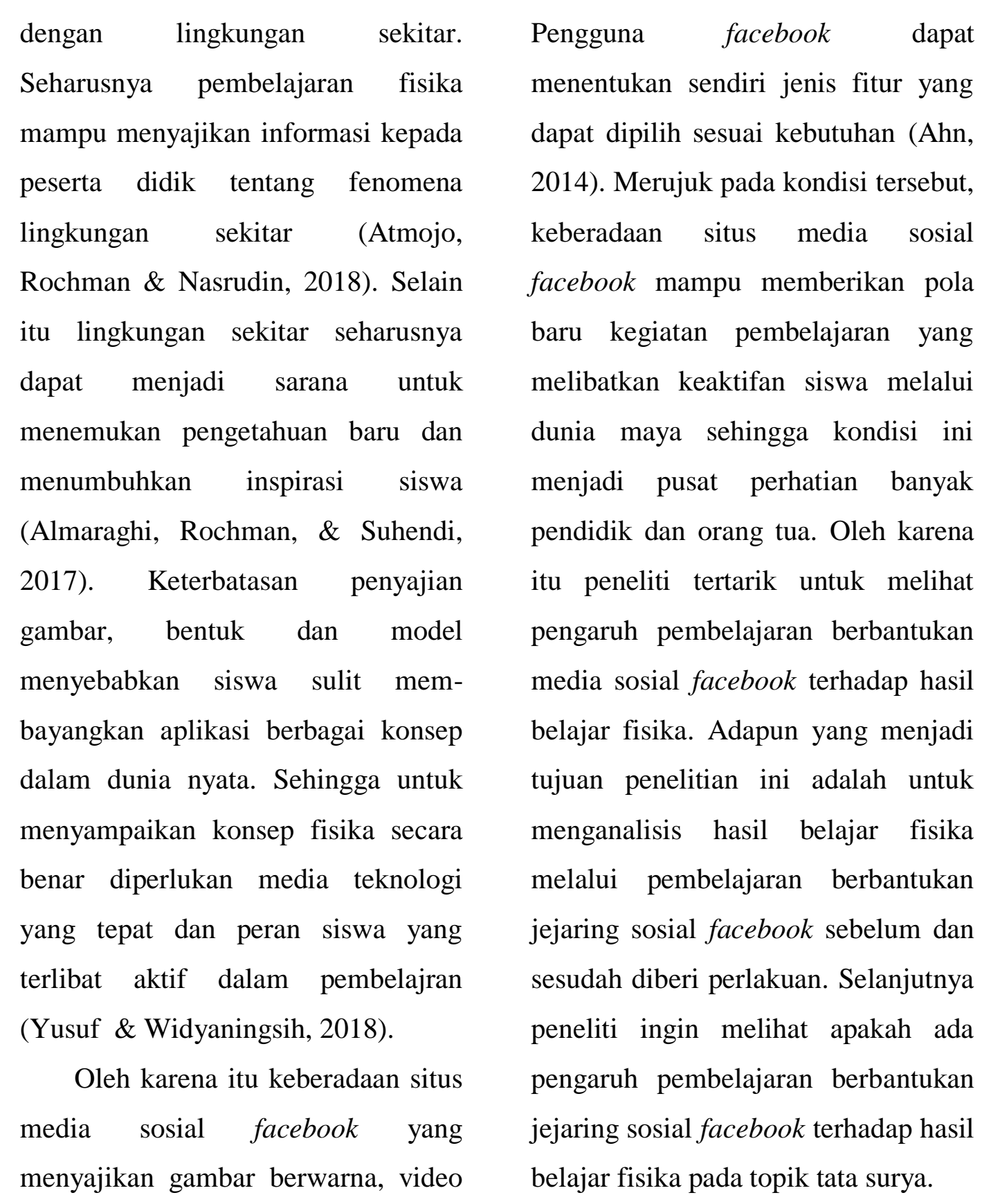
dan animasi dapat menjadi solusi tepat untuk peningkatan hasil pembelajaran fisika. Facebook juga memiliki berbagai fitur yang berbeda diantaranya daftar kontak, pesan pribadi, profil, pesan pribadi, obrolan, dan grup (Boyd \& Ellison, 2007).

\section{METODE}

Penelitian ini menggunakan metode kuasi eksperimen atau eksperimen semu. Rancangan yang didesain untuk penelitian ini adalah pretest-posttest control group 
Susilawati., I, W, Sari. - Pembelajaran Fisika Berbantukan ...

design. Penelitian ini dilakukan di MTSN Rukoh Banda Aceh.Populasi dalam penelitian ini adalah seluruh siswa kelas VII MTsN Rukoh Banda Aceh yang terdiri dari empat kelas. Penentuan sampel dalam studi ini dilakukan melalui teknik cluster random sampling, teknik ini dipilih karena semua dari kelas VII memiliki karakteristik yang sama. Melalui pengambilan sampel secara acak diperoleh dua kelas yaitu kelas VIIA dan kelas VIID yang dijadikan sampel dalam penelitian ini. Total seluruh sampel berjumlah 59 siswa yang terdiri dari 29 siswa kelas VIIA dan 30 siswa kelas VIID. Kelas VIIA sebagai kelas eksperimen diberi perlakuan dengan menggunakan pembelajaran berbantukan media sosial facebook, sedangkan kelas VIIB sebagai kelas kontrol diberikan perlakuan melalui metode diskusi tanyajawab. Teknik pengumpulan data dilakukan melalui tes dan observasi kegiatan pembelajaran. Ada dua variable yang akan diteliti dalam penelitian ini yaitu pembelajaran berbantukan jejaring sosial facebook sebagai variabel bebas yang dilambangkan dengan
(X) dan variabel hasil belajar fisika sebagai variabel terikat yang dilambangkan dengan (Y). Langkah awal teknik analisis data dilakukan melalui uji normalitas dan uji homogenitas. Selanjutnya untuk mengetahui adanya pengaruh yang signifikan dari perlakukan yang diberikan peneliti melakukan uji-t dengan menggunakan SPSS versi 20.

\section{HASIL DAN PEMBAHASAN}

Pembelajaran berbantukan jejaring social facebook mampu menarik perhatian siswa untuk ikut aktif terlibat. Pola ini diterapkan pada pokok bahasan tata surya. Selama ini siswa menganggap materi sulit dipahami jika tidak disertai dengan gambar dan video. Melalui pemanfaatan media sosial facebook siswa saling berbagi informasi, gambar serta video yang dapat dilihat langsung oleh teman kelompok dan memberi komentar terhadap tayangan video tersebut. Pada tahap awal guru bersama siswa membentuk grup komunikasi melalui akun facebook untuk masing-masing kelompok. Sebelum menjelaskan materi, guru telah 
Susilawati., I, W, Sari. - Pembelajaran Fisika Berbantukan ...

terlebih dahulu membagikan gambar dan materi pendukung topik tata surya untuk masing-masing kelompok. Guru menjelaskan materi sesuai sumber bacaan yang ada sambil menunjukkan gambar yang terlebih dahulu sudah di share ke masing-masing akun facebook. Guru meminta siswa untuk mengerjakan lembar diskusi siswa (LDS) yang ada dan menjawab pertanyaan yang ada sesuai dengan langkah kerja. Guru memberikan masalah untuk dipecahkan sesama teman kelompok sebagai bahan pengayaan.

Berdasarkan hasil observasi terlihat siswa aktif dalam memberi respon melalui grup massenger facebook. Keaktifan siswa untuk terlibat tidak hanya saat diseskolah, tetapi diluar jam sekolah mereka tetap berkomunikasi dan saling berbagi informasi. Hal ini sesuai dengan pendapat (Rusman \& Kurniawan.D, 2011; Yulita, 2013; Chatterjee, 2014; Jesse, 2015) yang menyatakan pembelajaran dengan menggunakan teknologi informasi seperti jejaring sosial dapat bermanfaat dalam melibatkan siswa secara aktif dalam kegiatan belajar tanpa dibatasi oleh ruang dan waktu. Kondisi ini juga dilatar belakangi seringnya siswa membuka aplikasi media sosial facebook yang telah menjadi saran komunikasi dalam keseharian remaja usia sekolah (Cheung, Chiu \& Lee, 2011; Lagiono, 2012).

Hasil pengujian normalitas peneliti meperoleh nilai signifikansi (Asym Sig 2 Tailed) kelas eksperimen $>0,05$ yaitu 0,08 dan nilai signifikansi (Asym Sig 2 Tailed) kelas kontrol > 0,05 yaitu 0,052 maka dapat disimpulkan data tersebut berdistribusi normal. Selanjutkan hasil perhitungan uji homogenitas pretest kelas eksperimen dan kontrol menunjukkan data homogen. Nilai signifikan diperoleh 0,624 menunjukkan nilai ini lebih dari 0,05. Sehingga peneliti menyimpulkan bahwa $\mathrm{H}_{0}$ diterima karena data mempunyai varians sama. Hasiluji homogenitas nilai posttest kelas eksperimen dan kontrol juga menunjukkan data yang homogen karena nilai signifikan lebih dari 0,05 yaitu nilai signifikan 
sebesar 0,596. Sehingga dapat disimpulkan bahwa $\mathrm{H}_{0}$ diterima.

Pengujian berikutnya yaitu uji Independent Sampel T-Test. Data hasil perhitungan diperoleh nilai rata-rata pretest $t_{\text {hitung }}$ sebesar 0,262 . Besaran $t_{\text {tabel }}$ pada taraf signifikan 0,05:2=0,025 diperoleh untuk $t_{\text {tabel }}$ sebesar 1,88. Nilai $t_{\text {hitung }} 0,262$ dan $\mathrm{t}_{\text {tabel }} 1,88$, artinya $\mathrm{t}_{\text {hitung }}<\mathrm{t}_{\text {tabel }}$ jadi $\mathrm{H}_{0}$ diterima dan $\mathrm{H}_{\mathrm{a}}$ ditolak. Data ini menunjukkan hasil uji beda terhadap nilai pretest kelas eksperimen dan kelas kontrol sama. Sehingga dapat disimpulkan bahwa siswa memiliki kemampuan yang relatif sama sebelum diberikan perlakuan.

Hasil analisis uji hipotesis dengan menggunakan Paired Sample T-Test diperoleh data bahwa nilai mean untuk pretest (sebelum diberikan perlakuan) sebesar 48,28 dan untuk posttest (setelah diberikan perlakuan) nilai mean meningkat menjadi 80,34. Berdasarkan data ini peneliti menyimpulkan bahwa nilai rata-rata posttest lebih besar dibandingkan nilai rata-rata pretest. Sehinggga data ini menunjukkan pembelajaran berbantukan jejaring sosial facebook berpengaruh terhadap hasil belajar fisika siswa kelas VII.

Selanjutnya hasil analisis uji $\mathrm{t}$ menggunakan spss terhadap nilai pretest dan post test diperoleh hasil nilai $\mathrm{t}$ 25,58 dengan probabilitas signifikansi $0,000<0,05$, mengacu pada $t_{\text {tabel }}$ diperoleh dengan $\mathrm{df}=28$ dan signifikan 5\% (2-tailed)=16,9. Nilai ini menunjukkan $t_{\text {tabel }}<t_{\text {hitung }}$ yaitu $16,9<25,58$ maka $\mathrm{H}_{0}$ ditolak dan $\mathrm{H}_{\mathrm{a}}$ diterima. Hasil ini menyimpulkan bahwa terdapat pengaruh pembelajaran berbantukan jejaring sosoal facebook terhadap hasil belajar siswa pada topik tata surya.

Berdasarkan hasil Paired Samples Test dan Paired samples correlations diperoleh nilai sig (2tailed) $0.000<0,05$ menunjukkan sangat signifikan. Hasil ini menyimpulkan adanya pengaruh yang signifikan hasil belajar setelah mendapatkan perlakuan dibandingkan dengan sebelum mendapatkan perlakuan. Sehingga data ini menunjukkan adanya pengaruh yang signifikan pada hasil belajar fisika melalui pembelajaran berbantukan jejaring social facebook. 


\section{Pembahasan}

Mengacu pada hasil pengujian hipotesis dan analisis data yang dilakukan pada hasil pretest siswa kelas eksperimen dengan hasil pretest siswa kelas kontrol sebelum diberi perlakuan menunjukkan tidak terdapat perbedaan. Sehingga data ini menggambarkan bahwa kondisi awal kedua kelas sama sebelum mendapatkan perlakuan. Pada awal pembelajaran nilai siswa cenderung masih rendah, hal ini wajar karena kedua kelas belum mendapat pembelajaran. Nilai pretest ini hanya sebagai gambaran kemampuan awal siswa. Harapannya setelah kedua kelas mendapatkan perlakuan masing-masing siswa akan memperoleh nilai yang lebih baik. Hal ini sesuai dengan pendapat Djamarah dan Zain (2010) yang menyatakan bahwa jika sebagian besar (75\% atau lebih) dari jumlah siswa memperoleh keberhasilan pada taraf rendah saat mengikuti kegiatan belajar, hendaknya kegiaratan pembelajaran berikutnya harus bersifat perbaikan.

Merujuk pada nilai posttest kelas yang menggunakan media sosial facebook mendapat hasil yang lebih baik dibanding kelas yang hanya menggunakan metode diskusi tanya jawab saja. Dalam prakteknya pembelajaran berbantukan media sosisal facebook mampu menarik minat dan perhatian siswa. Siswa terlibat aktif dalam diskusi baik didalam kelas maupun melalui forum grup facebook messenger. Melalui aplikasi ini siswa secara leluasa berbagi informasi terkait materi ajar baik berupa gambar maupun video. Ini merupakan salah satu keunggulan pembelajaran yang memanfaatkan perkembangan teknologi informasi sehingga siswa dapat melakukan aktivitas belajar diluar jam pelajaran. Hal ini sesuai dengan pendapat (Rusman \& Kurniawan, 2011) yang menyebutkan pembelajran akan menjadi mudah dengan pemanfaatan teknologi dan jaringan internet sehingga dapat diakses dimanapun berada.

Salah satu pemanfaatan teknologi internet yang dapat diakses dimana saja, kapan saja, multiuser serta menyajikan segala kemudahan sehingga menjadikannya salah satu 
Susilawati., I, W, Sari. - Pembelajaran Fisika Berbantukan ...

media yang dapat membantu keberhasilan pembelajaran. Oleh karena itu, fasilitas ini sangat baik digunakan untuk meningkatkan aktivitas pembelajaran.

Dilatarbelakangi aktivitas harihari siswa yang memang aktif menggunakan media facebook, dapat membantu mereka untuk belajar di luar jam pelajaran. Aktivitas siswa yang cukup intens dalam memperbaharui dan menelusuri profil facebooknya dapat dilakukan sambil disertai berkomunikasi dengan grup diskusi kelas dalam menyelesaikan tugas yang diberikan. Hal ini sesuai dengan pendapat (Richardson \& Stanyer, 2011; Singer, 2014) yang menyatakan bahwa sebagian besar waktu siswa dihabiskan untuk update profil dan menelusuri profil temannya. Sehingga ativitas ini dianggap akan lebih positif jika disertai dengan kebgiatan pembelajaran (Alvarez, Alarcon, \& Nussbaum, 2011; Chiang, Yang \& Hwang, 2014).

Melalui aplikasi grup messenger yang tersedia pada situs facebook, siswa lebih mudah belajar secara kolaboratif, bekerjasama dan berkomunikasi tidak hanya diruang kelas tetapi juga diluar waktu belajar. Jika siswa merasa senang untuk terlibat dalam kegiatan pembelajaran maka sangat memungkinkan capaian keberhasilan pembelajaran juga akan menjadi lebih baik.

Berdasarkan nilai $\mathrm{n}$-Gain menunjukkan adanya perbedaan yang signifikan hasil belajara siswa memalui pembelajaran berbantukan jejaring social facebook dibandingkan hasil belajara siswa yang diajarakan melalui motode pembelajaran diskusi biasa.Materi tata surya yang identik dengan bahan bacaan, gambar dan video sangat cocok diajarakan melalui melalui media facebook. Hal ini sesuai dengan temuan Ariyani (2010) yang melakukan kajian tentang pembelajaran fisika berbantukan media online facebook dan menyimpulkan bahwa metode pembelajaran ini memberi pengaruh yang signifikan terhadap hasil belajar fisika.

\section{Ucapan Terima Kasih}

Terimakasih kepada guru dan siswa MTsN Rukoh Banda Aceh yang 
Susilawati., I, W, Sari. - Pembelajaran Fisika Berbantukan ...

telah bersedia terlibat dalam penelitian ini. Ucapan terimakasih juga penulis tujukan kepada ketua jurusan pendidikan fisika Universitas Syiah Kuala beserta seluruh dosen yang telah memberikan support hingga selesainya penelitian dan terbitnya artikel ini.

\section{PENUTUP}

\section{Kesimpulan}

Pelaksanaan pembelajaran berbantukan media facebook yang dilakukan pada kelas eksperimen menunjukkan hasil belajar yang lebih baik dibandingkan dengan kelas kontrol yang hanya memberlakukan metode diskusi tanya jawab. Data ini menujukan bahwa pembelajaran berbantukan jejaring sosial facebook memberikan pengaruh terhadap hasil belajar fisika. Hasil pengujian menyimpulkan bahwa pembelajaran berbantukan jejaring sosial facebook memberikan pengaruh yang signifikan terhadap hasil belajar fisika pada topik tata surya. Temuan ini menunjukkan bahwa media sosial facebook dapat dimanfaatkan sebagai media dalam pembelajaran untuk meningkatkan hasil belajar siswa.

\section{Saran}

Penelitian selanjutnya perlu dilakukan pengkajian tentang motivasi dan minat siswa dalam penggunaan jejaring sosial facebook dalam pembelajaran. Aktivas dan interaksi sosial yang muncul saat menggunakan media sosial ini dalam pembelajaran juga perlu dilakukan penelitian lebih lanjut.

\section{DAFTAR PUSTAKA}

Abdelraheem, A. Y., \& Ahmed, A. M.(2018). The impact of using Mobile Social Network Applications on Students' Social Life. International Journal of Instruction, 11(2), 1-14.

Ahn,J. (2011). The effect of social network sites on adolescents' academic and social development: Current theories and controversies. Journal of the American Society for Information Science \& Technology, 62 (8),1435-1445.

Almaraghi, F. A., Rochman, C., \& Suhendi, H. Y. (2017). Profil literasi peserta didik terhadap mitigasi bencana gunung berapi di daerah sukaratu Tasikmalaya. Jurnal Wahana Pendidikan Fisika, 2(2), 32-35.

Alvarez, C., Alarcon, R., \& Nussbaum, Implementing
M. (2011). collaborative 
Susilawati., I, W, Sari. - Pembelajaran Fisika Berbantukan ...

learning activities in the classroom supported by one-to-one mobile computing: A design-based process. Journal of Systems and Software, 84(11),1961-1976.

Ariyani Fina. (2010). Pengaruh Pembelajaran Berbantukan Media Online Facebook Terhadap Hasil Belajar Fisika Pada Konsep Termodinamika. Skripsi tidak diterbitkan. Jakarta : Universitas Islam Negeri Syarif Hidayatullah.

Atmojo,T., Rochman, C., \&Nasrudin, D. (2018). Profil Literasi Konsep Fisika Peserta Didik Pada Mitigasi Bencana Hujan Es Antapani. Jurnal Pendidikan Fisika (JPF) UM Metro.,4(2).

Boyd, D., \& Ellison, N. B. (2007). Social network sites: Definition, history, and scholarship. Journal of Computer-Mediated

Communication, 13 (1), 210-230.

Chatterjee,S.(2014). Asociological outlook of mobile phoneuse in society. International Journal of Interdisciplinary and Multidisciplinary Studies (IJIMS), 11(6), 55-63.

Cheung, C. M. K., Chiu, P. Y., \& Lee, M. K. O. (2011). Online social networks:Why do students use facebook? Computers in Human Behavior, 27 .1337-1343

Chiang, T. H., Yang, S. J.,\& Hwang, G.J. (2014). An augmented realitybased mobile learning system to improve students' learning achievements and motivations innatural science inquiry activities.Educational Technology \& Society,17(4),352-365

Djamarah \& Aswan Zain. (2010). Strategi Belajar Mengajar. Jakarta: Rineka Cipta
Ellison, N. B., Steinfield , C., \& Lampe, C. (2007). Social capital and college students'use of online social network sites. Journal of Computer-Mediated Communications, 12, 1143-1168.

Fitiyadi, Herry. 2013. Integrasi Teknologi Informasi Komunikasi Dalam Pendidikan: Potensi Manfaat, Masyarakat Berbasis Pengetahuan, Pendidikan Nilai, Strategi Implementasi dan Pengembangan Profesional. Jurnal Pendidikan Teknologi dan Kejuruan, 21(3).

Irfan Yusuf, Sri Wahyu Widyaningsih. (2018). Pembelajaran PBL Berbantuan Lab-Vir Melalui Lesson Study Dalam Meningkatkan Kualitas Pembelajaran Fisika Umum Universitas Papua. Jurnal Pendidikan Fisika (JPF) UM Metro.,5 (2).

Jesse,G.(2015). Smartphone and App Usage among College Students: Using Smartphones Effectively for Social and Educational Needs. Conference on Information Systems and Computing Education. Wilmington, North Carolina USA

Lagiono. (2012). Pola Implementasi Jejaring Sosial Facebook Sebagai Media Pembelajaran. LENTERA jurnal ilmiah kependidikan, 7 (2)37-43.

Lytras,M. D., \& Garcia,R. (2008). Semantic Web applications: A framework for industry and business exploitation-What is needed for the adoption of the Semantic Web from the market and industry. International Journal of Knowledge and Learning, 4(1), 93-108. 
Mazer, J. P., Murphy, R. E., \& Simonds, C. J. (2007). I'll see you on "Facebook": The effects of computer-mediated teacher selfdisclosure on student motivation, affective learning, and classroom climate. Communication Education, 56 (1),1-17.

Murray, K. E., \& Waller,R. (2007). Social networking goes a broad. International Educator, 16(3),5659.

Richardson, J. E., \& Stanyer, J. (2011). Reader opinion in the digital age: Tabloid and broadsheet newspaper websites and the exercise of political voice. Journalism, 12 (8), 983-1003.

Roslina, \& Wahyuni, A. (2014)

Pengaruh Pengembangan Media Berbasis Ict Terhadap Hasil Pembelajaran Fisika SMA/MADi Provinsi Aceh. Jurnal Serambi Ilmu, 19 (2).

Rusman, Kurniawan. D. (2011). Model Pembelajaran TIK bagi Guru. Jakarta: Rajawali Press.

Sari, S. L., Widyanto, A., \& Kamal, S. (2017). Pengembangan media pembelajaran berbasis video animasi dalam Smartphone pada materi sistem kekebalan tubuh manusia untuk siswa kelas xi di SMA Negeri 5 Banda Aceh. Prosiding Seminar Nasional Biotik.

Supardi. 2010. Pengaruh Media Pembelajaran Dan Minat Belajar Terhadap Hasil Belajar Fisika. Jurnal Formatif . 2(1): 71-81

Yulita., Rustiyarso., \& Genjik, B. 2013. Analisis Pemanfaatan Media Jejaring Social Berbasis Computer Dalam Upaya Meningkatkan Hasil Belajar Siswa di SMPS. Skripsi tidak diterbitkan Pontianak:Untan. 